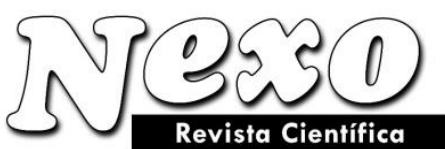

Vol. 33, No. 02, pp. 297-307/Diciembre 2020

\title{
Evaluation of Silicon and irrigation on three Safflower cultivars
}

\section{Evaluación de Silicio e irrigación en tres cultivares de Cártamo}

\author{
Mehdi Sadeghi, Foroud Bazrafshan, Mahdi Zare, Omid Alizadeh, Bahram Amiri \\ Assistant Professor of Agronomy, Department of Agriculture, Firouzabad Branch, Islamic Azad \\ University, Firouzabad, Iran.
}

Corresponding author email: Mahdi.zare2009@gmail.com

(recibido/received: 13-May-2020; aceptado/accepted: 13-July-2020)

\begin{abstract}
This study was performed to evaluation of interaction of silicon application and irrigation on agronomic and physiologic traits of safflower at 2018 and 2019. The experiment was conducted as a split plot factorial based on randomized complete block design with 3 replications. The irrigation was main factor (0,2 and 4 times during growth) and the sub-factor were silicon foliar application (at three levels: 0, 1 and $2 \mathrm{mM}$ ) and three safflower cultivars (Goldasht, Padideh and Golmehr). The studied traits were: number of seeds per boll and 1000-grain weight, number and weight of boll, number of lateral branches and branch diameter, plant weight and total plant weight, floret yield, grain yield, chlorophyll a and b, proline and antioxidant enzymes. According to results, treatments had significant effects on studied traits at 5 or $1 \%$ statistically level. 2 and 3 times irrigation led to 7 and $24 \%$ the increasing of seed yield in compare to control, respectively. It was obtained that 1 and $2 \mathrm{mM}$ silicon led to 25 and $15 \%$ the increase of seed yield in compare to control. Interaction between treatments showed that the highest seed yield $\left(500 \mathrm{~g} \mathrm{per}^{2}\right)$ was observed by Goldasht cultivar under 4-time irrigation and $2 \mathrm{mM}$ silicon. Therefore, it can be suggested that Goldasht with $2 \mathrm{mM}$ silicon be used to reduce the effects of dehydration.
\end{abstract}

Key words: Irrigation, Safflower, Silicon, Agronomic traits.

\section{RESUMEN}

Este estudio se realizó para evaluar la interacción de la aplicación de silicio y el riego en rasgos agronómicos y fisiológicos del cártamo en 2018 y 2019. El experimento se realizó como un factorial de parcela dividida basado en un diseño de bloques completos al azar con 3 repeticiones. El riego fue el factor principal (0, 2 y 4 veces durante el crecimiento) y el subfactor fue la aplicación foliar de silicio (en tres niveles: 0, 1 y $2 \mathrm{mM}$ ) y tres cultivares de cártamo (Goldasht, Padideh y Golmehr). Los rasgos estudiados fueron: número de semillas por cápsula y peso de 1000 granos, número y peso de cápsula, número de ramas laterales y diámetro de rama, peso de la planta y peso total de la planta, rendimiento del florete, rendimiento de grano, clorofila ayb, prolina y enzimas antioxidantes Según los resultados, los 
tratamientos tuvieron efectos significativos en los rasgos estudiados a un nivel estadístico del 5 o $1 \%$. El riego 2 y 3 veces condujo a un aumento de 7 y $24 \%$ en el rendimiento de semillas en comparación con el control, respectivamente. Se obtuvo que el silicio de 1 y $2 \mathrm{mM}$ condujo a un aumento de 25 y $15 \%$ del rendimiento de la semilla en comparación con el control. La interacción entre tratamientos mostró que el cultivar Goldasht observó un rendimiento de semilla más alto (500 g por m2) bajo riego por 4 tiempos y silicio $2 \mathrm{mM}$. Por lo tanto, se puede sugerir que se use Goldasht con silicio $2 \mathrm{mM}$ para reducir los efectos de la deshidratación.

Palabras clave: Riego, cártamo, silicio, rasgos agronómicos.

\section{INTRODUCCIÓN}

Understanding plant responses to irrigation and drought stress is essential; also there is a need to know possible physiological mechanisms of damage and drought avoidance for the genetic improvement of crops. Between plants, safflower, a strongly tap-rooted annual plant from the family Asteraceae, is native to the Middle East. It is resistant to saline conditions and to drought stresses (Eslam, Monirifar, \& Ghassemi, 2010) but it depends on the growth stage when the plant is facing stress. For example, Saini and Westgate (2000) pointed out that all of the reproductive subphases of safflower are sensitive to water deficit. Water stress during early reproductive growth stages reduces seed and/or flower numbers per capitulum. Ebrahimian, Seyyedi, Bybordi, and Damalas (2019) reported that seed yield reduction in safflower was mainly due to a reduction in seed weight and a reduction in seed number capsules. Drought stress disrupts the normal transportation of solutes, causes electron leakage, and triggers the production of reactive oxygen species (ROS), which create oxidative injury (Hussain et al., 2019), Rapid activation of enzymatic and nonenzymatic ROS-scavenging systems mediates drought tolerance characteristics in plants. Ghaffari, Tadayon, Nadeem, Cheema, and Razmjoo (2019) mentioned that drought stress caused a significant up-regulation in leaf proline content, malondialdehyde (MDA) content, hydrogen peroxide ( $\mathrm{H} 2 \mathrm{O} 2)$ content, ascorbate peroxidase, catalase, and peroxidase enzymatic activities in sugar beet. However, it was determined that application of some elements such as silicon can be effective in reducing the effects of stress. At this order, Gong, Chen, Zhao, Chen, and Zhou (2008) showed that silicon had significant effects on defense of wheat against oxidative stress under drought. Chen, Yao, Cai, and Chen (2011) mentioned that silicon application was useful to increase drought resistance of rice through the enhancement of photochemical efficiency and adjustment of the mineral nutrient absorption in rice plants. Gunes, Pilbeam, Inal, and Coban (2008) concluded that applied Si alleviates drought stress in sunflower cultivars by preventing membrane damage, although the cultivars showed genotypic variation in response to applied Si. Gunes, et al. (2008) reported that in sunflower cultivarsthe CAT activity was significantly decreased by drought stress, but supplemental Si increased it. In general, SOD and APX activities of the cultivars were increased by drought and decreased by application of Sattar et al. (2019) reported that foliar applied silicon improved water relations, stay green and enzymatic antioxidants activity of wheat in heat stress. The adversative impacts of drought stresses can be alleviated via different agricultural practices such as application of crop establishment or application of plant nutrients for maintaining a suitable level of water in plant leaves due to osmotic adjustment and stomatal conductance performance, consequently improving plant growth and productivity (Seleiman, 2019). So, at this research we evaluated the effects of silicon and irrigation interaction on three safflower cultivars. 


\section{METHODOLOGY}

The experiment was conducted as a split plot factorial based on randomized complete block design with three replications and at two years. The irrigation was main factor (control (0), 2 and 4 times during growth) and the sub-factor were silicon foliar application (at three levels: 0,1 and $2 \mathrm{mM}$ ) and three safflower cultivars (Goldasht, Padideh and Golmehr). The experiment was carried out on a land area of 1953 square meters, the length and width of each plot were 27 and $3 \mathrm{~m}$, respectively, and the distance between the two adjacent plots was 3 meters. Irrigation in control treatment was rainfed and 2 times irrigation done at stemming and budding stages, also 4 times treatment applied at stemming, budding, flowering, seeding. The studied traits were: number of seeds per boll and 1000-grain weight, number and weight of boll, number of lateral branches and branch diameter, plant weight and total plant weight, floret yield, grain yield, chlorophyll $\mathrm{a}$ and $\mathrm{b}$, proline and antioxidant enzymes. A spectrophotometer was used to measure chlorophyll, Light absorption at 645 and $663 \mathrm{~nm}$ was measured by spectrophotometer and Bates et al. (1973) method was used to measure proline. Peroxidase activity was measured using the method of Chance and Mahley (1955), also, Catalase enzyme activity was measured using a modified method of Abedi, (1984). Data were analyzed by SAS software and compared by means of Duncan's multiple range test at $5 \%$ level.

\section{RESULT AND DISCUSSION}

\subsection{Number of seeds per boll}

According to analysis of variances it was founded that cultivar had significant effects on number of seeds per bollat $5 \%$ statistically level (Table 1), also, Interaction between irrigation $\times$ silicon at $1 \%$ and irrigation $\times$ silicon $\times$ cultivars showed significant effect at $1 \%$ statistically level on Number of seeds per boll (Table 1). The irrigation treatments including 2 and 4 times led to 21 and 13 percentages the increase of Number of seeds per bollby the compare to rainfed treatment. Results of Istanbulluoglu (2009) showed that safflower was significantly affected by water stress during the sensitive late vegetative stage Between cultivars, the highest means of number of seeds per bollwith 21.4 value obtained by Padideh cultivar. In relation to interaction treatments, the highest means of number of seeds per bollwith 41.7 value observed by padideh cultivar under 2 times irrigation and zero silicon (Table 2), also with rainfed and $2 \mathrm{mM}$ silicon showed lowest Number of seeds per boll (Table 2).

\subsection{0 seed weight}

According to analysis of variances it was founded that effect of irrigation treatments and cultivar had significant effects on 1000seed weight at $1 \%$ statistically level (table 1), also, Interaction between irrigation $\times$ cultivars, showed significant effect at $5 \%$ statistically level on 1000seed weight (Table 1).

The 2 and 4 times irrigation treatments led to 7 and 5 percentages the increase of 1000seed weight by the compare to rainfed treatment. According to results Tayebi, Afshari, Farahvash, MASOOD, and Nezarat (2012) the impact of drought stress on plant dry weight and leaf dry weight, plant height, number of branches and sub-shrubs, capitul in plant and seed in capitul as well as seed yield was significant. Between cultivars, the highest means of 1000seed weight with 
37.6 value obtained by Goldasht cultivar. In relation to interaction treatments, the highest means of 1000 seed weight with $44.3 \mathrm{~g}$ value observed by Goldasht cultivar under 4 times irrigation and $1 \mathrm{mM}$ silicon (Table 2), also with 4 times irrigation and $2 \mathrm{mM}$ silicon showed lowest 1000seed weight (Table 2). Ashrafi and Razmjoo (2010) showed that drought stress reduced the amount safflower yield in all cultivars.

\subsection{Number of boll}

According to analysis of variances it was founded that effect of irrigation treatments and cultivar had significant effects on number of boll at $5 \%$ statistically level (Table 1), also, Interaction between irrigation $\times$ silicon and silicon $\times$ cultivars, showed significant effect at $5 \%$ statistically level on Number of boll (Table 1). The irrigation treatment including 4 times led to 19 percentages the increase of Number of boll by the compare to rainfed treatment. The 1 and $2 \mathrm{mM}$ of silicon showed 7 and 10 the increase of number of boll the compare to control treatment.

Silicon is an important micronutrient for healthy and competitive growth of all cereals including rice in Asia (Brunings et al., 2009). Role of silicon in plant health and growth has been investigated in silicon accumulating crops and it seemed significantly effecting (Jinab, Solond, \& Varietel, 2008). Research evidences proved that adequate uptake of silicon ( $\mathrm{Si}$ ) can increase the tolerance of agronomic crops especially rice to both abiotic and biotic stress (Ma \& Takahashi, 2002). Between cultivars, the highest means of Number of boll with 465.0 per $\mathrm{m}^{2}$ value obtained by Goldasht cultivar.

In relation to interaction treatments, the highest means of Number of boll with 780 per $\mathrm{m}^{2}$ value observed by Goldasht cultivar under 4 times irrigation and $2 \mathrm{mM}$ silicon (Table 2), also padideh with rainfed and zero silicon showed lowest Number of boll (Table 2).

\subsection{Boll weight}

According to analysis of variances it was founded that effect of irrigation treatments and cultivar had significant effects on Boll weight at 1\% statistically level (Table 1), also, Interaction between silicon $\times$ cultivars, irrigation $\times$ silicon $\times$ cultivars showed significant effect at $1 \%$ statistically level on Boll weight (Table 1). The irrigation treatments including 2 and 4 times led to 40 and 17 percentages the increase of boll weight by the compare to rainfed treatment.

Between cultivars, the highest means of Boll weight with $2.57 \mathrm{~g}$ value obtained by Goldasht cultivar. In relation to interaction treatments, the highest means of Boll weight with 5.97 value observed by cultivar under 4 times irrigation and $2 \mathrm{mM}$ silicon (Table 2), also with rainfed and zero silicon showed lowest Boll weight (Table 2).

\subsection{Branch Number}

According to analysis of variances it was founded that effect of silicon and cultivar had significant effects on branch number at 5 and $1 \%$ statistically level, respectively (Table 1), also, Interaction between irrigation $\times$ silicon, irrigation $\times$ cultivars, silicon $\times$ cultivars, irrigation $\times$ silicon $\times$ cultivars showed significant effect at $1 \%$ statistically level on branch number (Table 1). The 1 and $2 \mathrm{mM}$ of silicon showed 18 and 9 the increase of branch number the compare to control treatment. Between cultivars, the highest means of branch number with 258 per $\mathrm{m}^{2}$ 
value obtained by Goldasht cultivar. In relation to interaction treatments, the highest means of branch number with 312 per $\mathrm{m}^{2}$ value observed by Goldasht cultivar under 4 times irrigation and $1 \mathrm{mM}$ silicon (Table 2), also Padideh with rainfed and zero silicon showed lowest branch number (156 per $\mathrm{m}^{2}$ ) (Table 2). Eslam, et al. (2010) reported the significant decrease in the number of seeds per capitulum, 1000-seeds weight, harvest index, and seed and oil yields under water deficit conditions, it seems that drought during the seed filling stage decreases seed and oil yields, mainly through their components.

\subsection{Plant weight}

According to analysis of variances it was founded that cultivar had significant effects on plant weight at $1 \%$ statistically level (Table 1), also, Interaction between irrigation $\times$ silicon, irrigation $\times$ cultivars, irrigation $\times$ silicon $\times$ cultivars showed significant effect at $5 \%$ statistically level on Plant weight (Table 1). Between cultivars, the highest means of plant weight with $157 \mathrm{~cm}$ value obtained by cultivar. In relation to interaction treatments, the highest means of plant weight with $172 \mathrm{~cm}$ value observed by cultivar under 4 times irrigation and $2 \mathrm{mM}$ silicon (Table 2), also Padide with rainfed and zero silicon showed lowest plant weight (Table 2).

\subsection{Seed yield}

According to analysis of variances it was founded that effect of irrigation treatments and cultivar had significant effects on Seed yield at 1\% statistically level (Table 1) and silicon treatment had significant effect at 5\% statistically level. The irrigation treatments including 2 and 4 times led to 7 and 24 percentages the increase of Seed yield by the compare to rainfed treatment. The 1 and $2 \mathrm{mM}$ of silicon showed 25 and 15 the increase of Seed yield the compare to control treatment. Between cultivars, the highest means of Seed yield with 330 g.m ${ }^{-2}$ value obtained by Goldasht cultivar.

In relation to interaction treatments, the highest means of Seed yield with 500 g.m ${ }^{-2}$ value observed by Goldasht cultivar under 4 times irrigation and $2 \mathrm{mM}$ silicon (table 2), at rainfed condition highest seed yield $\left(434\right.$ g. $\left.\mathrm{m}^{-2}\right)$ obtained by Goldasht cultivar with $1 \mathrm{mM}$ silicon treatment and at 2times irrigation treatment the highest seed yield $\left(407 \mathrm{~g} . \mathrm{m}^{-2}\right)$ optained by Goldasht cultivar with $2 \mathrm{mM}$ silicon treatment, so, this cultivar had yield stability under stress and non-stress conditions. Movahhedy-Dehnavy, Modarres-Sanavy, and Mokhtassi-Bidgoli (2009) evaluated drought stress on yield of safflowers and they reported the decrease in seed yield, total biomass, number of capitula per plant and plant height each growing season by withholding irrigation at various growth stages. Based on the results of Omidi (2009), interruption of irrigation at seed development stage has less effect on seed yield but can save irrigation water in safflower farms. 
Table 1. analysis of variances for agronomy traits in responses to irrigation, silicon and cultivar

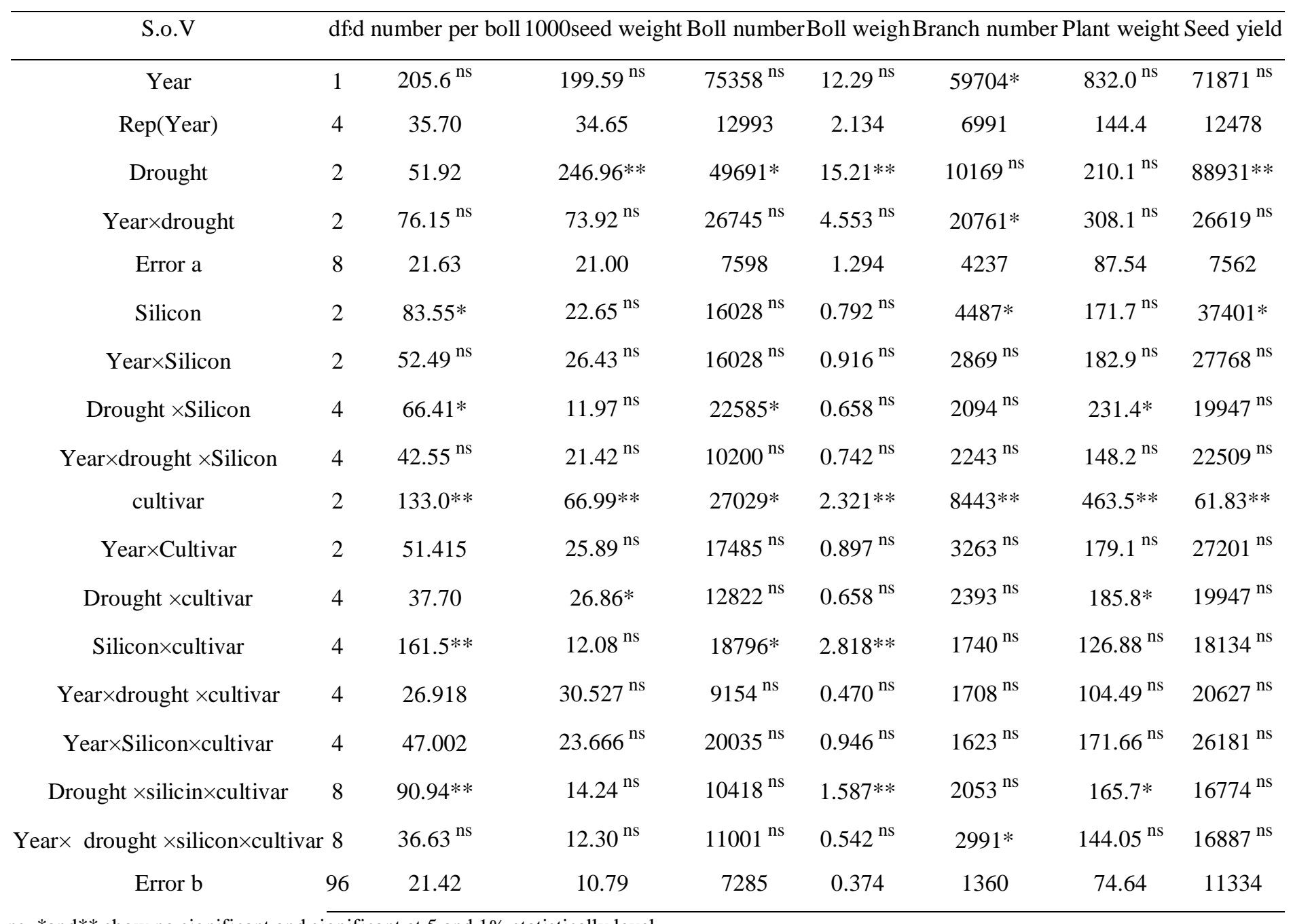

ns, *and** show no significant and significant at 5 and $1 \%$ statistically level 
Table 2. Mean comparison for studied traits in response to experiment treatments

\begin{tabular}{|c|c|c|c|c|c|c|c|c|c|c|c|c|c|c|c|c|}
\hline irrigation & silicon & Cultivars & $\begin{array}{l}\text { Seed } \\
\text { per } \\
\text { boll } \\
\end{array}$ & & 1000 seed weight $(\mathrm{g})$ & & Boll number $/ \mathrm{m}^{2}$ & & $\begin{array}{c}\text { Boll } \\
\text { weight } \\
\text { (g) }\end{array}$ & & Branch number $/ \mathrm{m}^{2}$ & & $\begin{array}{c}\text { Seed } \\
\text { yield } \\
\left(\mathrm{g} / \mathrm{m}^{2}\right)\end{array}$ & & $\begin{array}{l}\text { Plant } \\
\text { weight } \\
(\mathrm{g})\end{array}$ & \\
\hline \multirow[t]{9}{*}{0} & 0 & Goldasht & 17.0 & bcde & 35.4 & bcde & 390 & bcd & 2.73 & bcde & 242 & $a b c$ & 221.0 & abcd & 2018 & defg \\
\hline & & Padideh & 16.0 & bcde & 25.9 & fgh & 280 & d & 1.83 & cdef & 156 & $\mathrm{c}$ & 179.3 & bcd & 1275 & $\mathrm{fg}$ \\
\hline & & & 10.5 & de & 28.3 & defgh & 453 & bcd & 0.99 & $\mathrm{f}$ & 188 & $\mathrm{bc}$ & 131.2 & $\mathrm{~cd}$ & 1558 & defg \\
\hline & 1 & Goldasht & 20.6 & bcde & 36.3 & abcd & 361 & bcd & 2.85 & bcd & 228 & $a b c$ & 434.6 & $a b$ & 3611 & cdefg \\
\hline & & Padideh & 18.6 & bcde & 26.5 & fgh & 444 & bcd & 2.20 & cdef & 237 & $a b c$ & 216.9 & abcd & 2832 & cdefg \\
\hline & & & 17.7 & bcde & 30.0 & cdefg & 420 & bcd & 1.51 & cdef & 252 & $a b c$ & 221.4 & abcd & 3295 & cdefg \\
\hline & 2 & Goldasht & 18.4 & bcde & 34.1 & bcdef & 438 & bcd & 1.72 & cdef & 258 & $a b$ & 284.0 & abcd & 2761 & cdefg \\
\hline & & Padideh & 19.7 & bcde & 27.1 & efgh & 468 & bcd & 2.51 & bcdef & 216 & $a b c$ & 254.2 & abcd & 1416 & $\mathrm{fg}$ \\
\hline & & & 9.3 & $\mathrm{e}$ & 25.8 & fgh & 351 & bcd & 1.09 & ef & 196 & $\mathrm{bc}$ & 95.4 & d & 2017 & defg \\
\hline \multirow[t]{9}{*}{2} & 0 & Goldasht & 16.7 & bcde & 36.1 & abcd & 461 & bcd & 3.01 & $\mathrm{bc}$ & 222 & $a b c$ & 280.9 & abcd & 4550 & bcde \\
\hline & & Padideh & 41.7 & $\mathrm{a}$ & 30.8 & cdefg & 318 & $\mathrm{~cd}$ & 5.83 & $\mathrm{a}$ & 199 & $\mathrm{bc}$ & 354.1 & abcd & 7002 & $a b$ \\
\hline & & & 13.0 & bcde & 28.1 & defgh & 420 & bcd & 1.19 & def & 180 & $\mathrm{bc}$ & 153.7 & bcd & 1493 & efg \\
\hline & 1 & Goldasht & 13.5 & bcde & 40.8 & $a b$ & 462 & bcd & 3.91 & $\mathrm{~b}$ & 262 & $\mathrm{ab}$ & 195.5 & bcd & 4053 & cdefg \\
\hline & & Padideh & 21.3 & bcde & 25.0 & gh & 330 & bcd & 2.97 & $\mathrm{bc}$ & 264 & $a b$ & 169.0 & bcd & 2844 & cdefg \\
\hline & & & 15.9 & bcde & 31.6 & cdefg & 324 & bcd & 1.52 & cdef & 197 & $\mathrm{bc}$ & 162.8 & bcd & 1178 & $\mathrm{~g}$ \\
\hline & 2 & Goldasht & 19.3 & bcde & 38.1 & $a b c$ & 372 & bcd & 3.01 & $\mathrm{bc}$ & 246 & $a b c$ & 407.4 & $a b c$ & 3626 & cdefg \\
\hline & & Padideh & 15.9 & bcde & 27.5 & defgh & 420 & bcd & 1.79 & cdef & 258 & $a b$ & 132.0 & $\mathrm{~cd}$ & 1280 & $\mathrm{fg}$ \\
\hline & & & 22.7 & bcd & 32.3 & bcdefg & 476 & bcd & 1.22 & def & 255 & $a b c$ & 329.1 & abcd & 7984 & $\mathrm{a}$ \\
\hline \multirow[t]{9}{*}{4} & 0 & Goldasht & 18.0 & bcde & 33.4 & bcdefg & 369 & bcd & 1.68 & cdef & 257 & $a b$ & 218.1 & abcd & 5583 & $a b c$ \\
\hline & & Padideh & 22.8 & bcd & 30.7 & cdefg & 387 & bcd & 1.84 & cdef & 244 & $a b c$ & 269.4 & abcd & 1714 & defg \\
\hline & & & 11.7 & cde & 26.9 & efgh & 552 & $\mathrm{~b}$ & 1.41 & cdef & 234 & $a b c$ & 172.9 & bcd & 4380 & bcdef \\
\hline & 1 & Goldasht & 16.4 & bcde & 44.3 & $\mathrm{a}$ & 552 & $\mathrm{~b}$ & 2.01 & cdef & 312 & $\mathrm{a}$ & 436.6 & $a b$ & 3142 & cdefg \\
\hline & & Padideh & 19.1 & bcde & 29.7 & cdefg & 528 & $\mathrm{bc}$ & 1.73 & cdef & 240 & $a b c$ & 311.8 & abcd & 3748 & cdefg \\
\hline & & & 23.7 & $\mathrm{bc}$ & 28.5 & defgh & 486 & bcd & 1.64 & cdef & 279 & $a b$ & 345.9 & abcd & 1714 & defg \\
\hline & 2 & Goldasht & 24.8 & $\mathrm{~b}$ & 40.5 & $\mathrm{ab}$ & 780 & $\mathrm{a}$ & 2.28 & cdef & 300 & $\mathrm{a}$ & 500.6 & $\mathrm{a}$ & 4641 & bcd \\
\hline & & Padideh & 18.3 & bcde & 30.0 & cdefg & 312 & $\mathrm{~cd}$ & 1.84 & cdef & 186 & $\mathrm{bc}$ & 180.7 & bcd & 5783 & $a b c$ \\
\hline & & & 13.5 & bcde & 20.5 & $\mathrm{~h}$ & 377 & bcd & 5.97 & $\mathrm{a}$ & 189 & $\mathrm{bc}$ & 100.2 & $\mathrm{~d}$ & 67.3 & $\mathrm{~g}$ \\
\hline
\end{tabular}




\subsection{Total Chlorophyll content}

According to analysis of variances it was founded that effect of irrigation treatments and silicon had significant at 5\% statistically level and cultivar had significant effects on total chlorophyll content at $1 \%$ statistically level (Table 1), also, Interaction between irrigation $\times$ cultivars, irrigation $\times$ silicon $\times$ cultivars showed significant effect at $5 \%$ statistically level on total chlorophyll content (Table 1). The irrigation treatments including 2 and 4 times led to 9 and 8 percentages the increase of total chlorophyll content by the compare to rainfed treatment. The $1 \mathrm{mM}$ of silicon showed 5\% the increase of total chlorophyll content the compare to control treatment.

Between cultivars, the highest means of total chlorophyll content with $3.62 \mathrm{mg} / \mathrm{gfw}$ value obtained by Goldasht cultivar. In relation to interaction treatments, the highest means of total chlorophyll content with $4.2 \mathrm{mg} / \mathrm{gfw}$ value observed by Goldasht cultivar under 4 times irrigation and $1 \mathrm{mM}$ silicon (Table 2), also with 4 times irrigation and $2 \mathrm{mM}$ silicon showed lowest total chlorophyll content (Table 2).

\subsection{Proline}

According to analysis of variances it was founded that effect of irrigation treatments was significant at $1 \%$, silicon and cultivar had significant effects on proline at $5 \%$ statistically level (Table 1), also, Interaction between irrigation $\times$ cultivars, and irrigation $\times$ silicon $\times$ cultivars showed significant effect at $5 \%$ statistically level on proline (Table 1). The irrigation treatments including 2 and 4 times led to 41 and 61 percentages the decrease of proline by the compare to rainfed treatment. The 1 and $2 \mathrm{mM}$ of silicon showed no significant effect on proline. Between cultivars, the highest means of proline with 0.10 value obtained by Goldasht cultivar. In relation to interaction treatments, the highest means of proline with 0.16 value observed by Goldasht cultivar under rainfed treatment and 0 silicon (Table 2), also with 4times irrigation and 3mM silicon showed lowest proline (Table 2). Crusciol, Pulz, Lemos, Soratto, and Lima (2009) reported that proline concentrations in potato increased under lower water availability and higher $\mathrm{Si}$ availability in the soil, which indicates that $\mathrm{Si}$ may be associated with plant osmotic adjustment. Water deficit and $\mathrm{Si}$ application decreased total sugars and soluble proteins concentrations in the leaves.

\subsection{Catalase activity}

According to analysis of variances it was founded that effect of irrigation treatments was at $1 \%$ statistically level, silicon and cultivar had significant effects on catalase activity at 5\% statistically level (Table 1), also, Interaction between irrigation $\times$ silicon, irrigation $\times$ cultivars, irrigation $\times$ silicon $\times$ cultivars showed significant effect at $5 \%$ statistically level on catalase activity (Table 1). The irrigation treatments including 2 and 4 times led to 24 and 36 percentages the decrease of catalase activity by the compare to rainfed treatment. The 1 and $2 \mathrm{mM}$ of silicon showed 40 and 69 the decrease of catalase activity the compare to control treatment. Between cultivars, the highest means of catalase activity with 0.21 (U/g of protein) value obtained by cultivar. In relation to interaction treatments, the highest means of catalase activity observed by with rainfed and zero silicon (Table 2), also with 4times irrigation and $2 \mathrm{mM}$ of silicon showed lowest catalase activity (Table 2). 


\subsection{Peroxidase activity}

According to analysis of variances it was founded that effect of irrigation treatments and cultivars had significant effect at $1 \%$ statistically level, silicon had significant effects on peroxidase activity at $5 \%$ statistically level (Table 1), also, Interaction between irrigation $\times$ cultivars, irrigation $\times$ silicon $\times$ cultivars showed significant effect at $5 \%$ statistically level on peroxidase activity (Table 1). The irrigation treatments including 2 and 4 times led to 24 and 53 percentages the decrease of peroxidase activity by the compare to rainfed treatment. The 1 and $2 \mathrm{mM}$ of silicon showed 42 and 65 the decrease of peroxidase activity the compare to control treatment. Between cultivars, the highest means of peroxidase activity with peroxidase activity with 0.78 $\mathrm{U} / \mathrm{g}$ of protein value obtained by cultivar.

In relation to interaction treatments, the highest means of peroxidase activity with $1.75 \mathrm{U} / \mathrm{g}$ of protein value observed by cultivar under rainfed and zero silicon (Table 2), also Goldasht with 4 times of orrigation and $2 \mathrm{mM}$ silicon showed lowest peroxidase activity (Table 2).

Nolla, de Faria, Korndoerfer, and da Silva (2012) reported the use of silicate resulted in more resistant and productive rice plants, especially under water stress. Even under greater water availability conditions, the use of silicate resulted in greater rice yield. The results of Karmollachaab, Bakhshandeh, Gharineh, Telavat, and Fathi (2013) showed a positive effect of silicon on wheat plant under stress conditions that were higher than when the plant is under no stress condition. Gunes, et al. (2008) by research on influence of Silicon on Sunflower Cultivars under Drought Stress reported that the CAT activity was significantly decreased by drought stress, but supplemental Si increased it. In general, SOD and APX activities of the cultivars were increased by drought and decreased by application of Si. The nonenzymatic antioxidant activity of the cultivars was significantly increased by Si under drought stress.

It ermined that the foliage applied Si under water deficit conditions stimulated plant growth and photosynthetic attributes, water relations, transpiration rate, and chlorophyll contents. In addition, an increase in antioxidants enzymatic activity was recorded under water deficit conditions (Sattar et al., 2020). It founded that $\mathrm{Si}$ is able to positively modulate nitrogen metabolism and antioxidant enzyme activities in sunflower plants in order to alleviate the harmful effects of stress (Conceição et al., 2019), Water-stress alleviation and yield improvement by Si application was attributable to partly improved osmotic adjustment and antioxidant activity as well as to more favorable water status under stress conditions (Maghsoudi, Emam, Ashraf, \& Arvin, 2019).

\section{CONCLUSIONES}

Based on the present work, it can be concluded that applied Si alleviates drought stress in sunflower cultivars by preventing membrane damage, although the cultivars showed genotypic variation in response to applied Si. In drought stress condition, best cultivar was Goldasht with 434.6g seed yield under $1 \mathrm{mM}$ silicon treatment. 


\section{REFERENCIAS}

Ashrafi, E., \& Razmjoo, K. (2010). Effect of irrigation regimes on oil content and composition of safflower (Carthamus tinctorius L.) cultivars. Journal of the American Oil Chemists' Society, 87(5), 499-506.

Brunings, A. M., Datnoff, L. E., Ma, J. F., Mitani, N., Nagamura, Y., Rathinasabapathi, B., \& Kirst, M. (2009). Differential gene expression of rice in response to silicon and rice blast fungus Magnaporthe oryzae. Annals of Applied Biology, 155(2), 161-170.

Chen, W., Yao, X., Cai, K., \& Chen, J. (2011). Silicon alleviates drought stress of rice plants by improving plant water status, photosynthesis and mineral nutrient absorption. Biological trace element research, 142(1), 67-76.

Conceição, S. S., Oliveira Neto, C. F. D., Marques, E. C., Barbosa, A. V. C., Galvão, J. R., Oliveira, T. B. D., ... \& Gomes-Filho, E. (2019). Silicon modulates the activity of antioxidant enzymes and nitrogen compounds in sunflower plants under salt stress. Archives of Agronomy and Soil Science, 65(9), 1237-1247.

Crusciol, C. A., Pulz, A. L., Lemos, L. B., Soratto, R. P., \& Lima, G. P. (2009). Effects of silicon and drought stress on tuber yield and leaf biochemical characteristics in potato. Crop science, 49(3), 949-954.

Ebrahimian, E., Seyyedi, S. M., Bybordi, A., \& Damalas, C. A. (2019). Seed yield and oil quality of sunflower, safflower, and sesame under different levels of irrigation water availability. Agricultural Water Management, 218, 149-157.

Eslam, B. P., Monirifar, H., \& Ghassemi, M. T. (2010). Evaluation of late season drought effects on seed and oil yields in spring safflower genotypes. Turkish Journal of Agriculture and Forestry, 34(5), 373-380.

Ghaffari, H., Tadayon, M. R., Nadeem, M., Cheema, M., \& Razmjoo, J. (2019). Proline-mediated changes in antioxidant enzymatic activities and the physiology of sugar beet under drought stress. Acta physiologiae plantarum, 41(2), 23.

Gong, H. J., Chen, K. M., Zhao, Z. G., Chen, G. C., \& Zhou, W. J. (2008). Effects of silicon on defense of wheat against oxidative stress under drought at different developmental stages. Biologia Plantarum, 52(3), 592-596.

Gunes, A., Pilbeam, D. J., Inal, A., \& Coban, S. (2008). Influence of silicon on sunflower cultivars under drought stress, I: Growth, antioxidant mechanisms, and lipid peroxidation. Communications in Soil Science and Plant Analysis, 39(13-14), 1885-1903.

Hussain, S., Rao, M. J., Anjum, M. A., Ejaz, S., Zakir, I., Ali, M. A., ... \& Ahmad, S. (2019). Oxidative stress and antioxidant defense in plants under drought conditions. In Plant abiotic stress tolerance (pp. 207-219). Springer, Cham.

Istanbulluoglu, A. (2009). Effects of irrigation regimes on yield and water productivity of safflower (Carthamus tinctorius L.) under Mediterranean climatic conditions. Agricultural Water Management, 96(12), 1792-1798.

Jinab, H., Solond, M., \& Varietel, M. (2008). Functional food product development: Book.

Karmollachaab, A., Bakhshandeh, A., Gharineh, M., Telavat, M. M., \& Fathi, G. (2013). Effect of silicon application on physiological characteristics and grain yield of wheat under drought stress condition. International Journal of Agronomy and Plant Production, 4(1), 30-37.

Ma, J. F., \& Takahashi, E. (2002). Soil, fertilizer, and plant silicon research in Japan. Elsevier.

Maghsoudi, K., Emam, Y., Ashraf, M., \& Arvin, M. J. (2019). Alleviation of field water stress in wheat cultivars by using silicon and salicylic acid applied separately or in combination. Crop and Pasture Science, 70(1), 36-43. 
Movahhedy-Dehnavy, M., Modarres-Sanavy, S. A. M., \& Mokhtassi-Bidgoli, A. (2019). Foliar application of zinc and manganese improves seed yield and quality of safflower (Carthamus tinctorius L.) grown under water deficit stress. Industrial Crops and Products, 30(1), 82-92.

Nolla, A., de Faria, R. J., Korndoerfer, G. H., \& da Silva, T. B. (2012). Effect of silicon on drought tolerance of upland rice. Journal of Food, Agriculture \& Environment, 10(1 part 1), 269-272.

Omidi, A. H. (2009). Effect of drought stress at different growth stages on seed yield and some agro-physiological traits of three spring safflower cultivars. Seed and Plant Production Journal, (1).

Sattar, A., Cheema, M. A., Sher, A., Ijaz, M., Ul-Allah, S., Nawaz, A., ... \& Ali, Q. (2019). Physiological and biochemical attributes of bread wheat (Triticum aestivum L.) seedlings are influenced by foliar application of silicon and selenium under water deficit. Acta Physiologiae Plantarum, 41(8), 146.

Sattar, A., Cheema, M. A., Sher, A., Ijaz, M., Wasaya, A., Yasir, T. A., ... \& Hussain, M. (2020). Foliar Applied Silicon Improves Water Relations, Stay Green and Enzymatic Antioxidants Activity in Late Sown Wheat. Silicon, 12(1), 223-230.

Seleiman, M. F. (2019). Use of plant nutrients in improving abiotic stress tolerance in wheat. In Wheat Production in Changing Environments (pp. 481-495). Springer, Singapore.

Tayebi, A., Afshari, H., Farahvash, F., MASOOD, S. J., \& Nezarat, S. (2012). Effect of drought stress and different planting dates on safflower yield and its components in Tabriz region. 